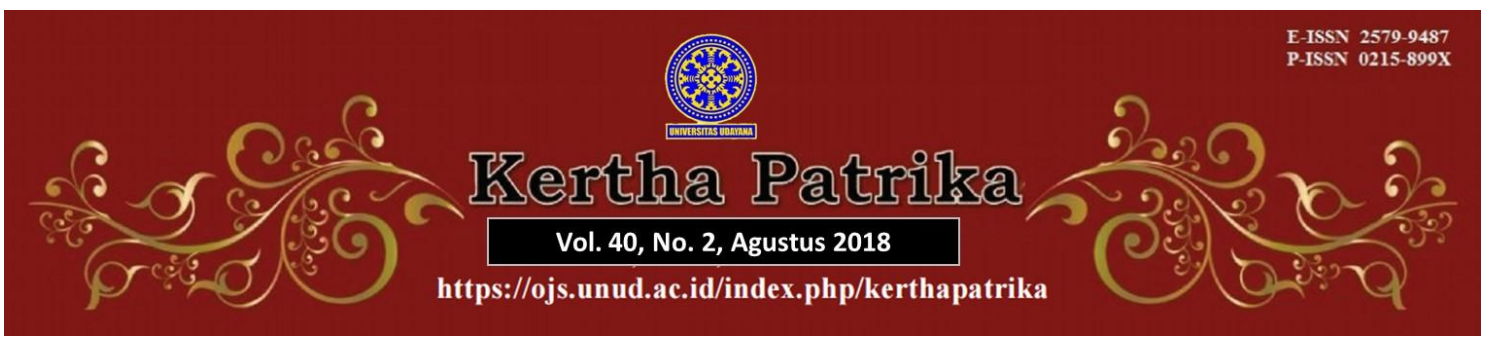

\title{
Kewenangan Notaris dalam Transaksi Jual Beli Tanah dan Bangunan: Studi Kasus Penahanan Sertipikat Hak Guna Bangunan
}

\section{Gusti Ayu Agung Devi Maharani Ariatmaja1}

${ }^{1}$ Magister Kenotariatan Universitas Udayana, E-mail: igstdevi@yahoo.com

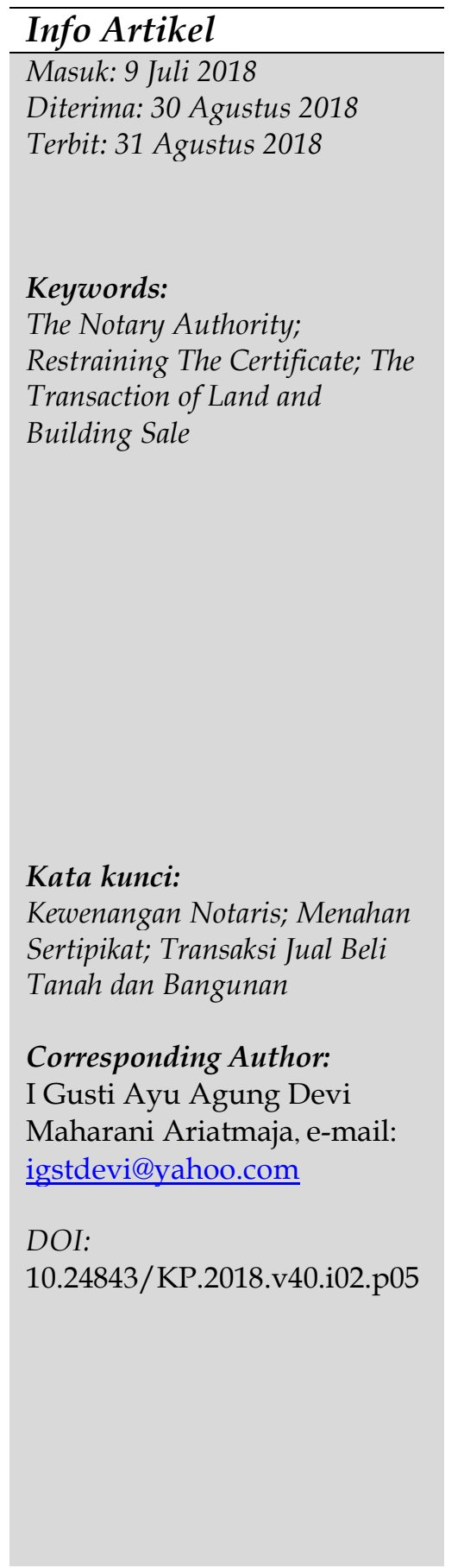

\begin{abstract}
The notary in his/her official duty must be able to provide service and legal counseling to the society and to act based on prevailing law in order to create legal certainty. A Land sale and purchase transaction is an activity to transfer ownership rights from the seller to the buyer. The willingness of the parties is then incorporated into the notarial deed, to be further approved by the PPAT. There was a case when a Notary kept or retained the certificate during the sale and purchase agreement was made. This scientific work aims to analyze the authority of Notaries in the sale and purchase transactions of land and buildings, as well as to analyze the legal consequences for Notaries who keep land certificate during sale and purchase transactions. This research is a normative legal research that uses statutory and case approaches. The results show that the Notary has authority in the field of land in accordance with Article 15 paragraph (2) letter $f$ of Law Number 2 of 2014 concerning Notary Position, but does not have the authority to hold / keep the certificate. The legal consequences related to the authority of a notary hold or keep a notary certificate can be subject to sanctions, among others, in the form of verbal or written warning from the Regional Oversight Council.
\end{abstract}

Abstrak
Notaris dalam tugas jabatannya harus dapat memberikan
pelayanan dan penyuluhan hukum bagi masyarakat serta
bersikap sesuai aturan hukum guna menciptakan kepastian
hukum. Transaksi jual beli tanah merupakan kegiatan
melakukan pemindahan hak milik dari penjual kepada
pembeli. Keinginan dari para pihak kemudian dituangkan
ke dalam akta untuk selanjutnya mendapat pengesahan
Pejabat Pembuat Akta Tanah PPAT. Terdapat suatu kasus
yaitu seorang Notaris yang menyimpan atau menahan
sertipikat pada saat dibuatnya akta pengikatan jual beli.
Karya ilmiah ini bertujuan untuk menganalisis
kewenangan Notaris dalam transaksi jual beli tanah dan
bangunan, serta untuk menganalisis akibat hukum bagi
Notaris yang melakukan penahana sertipikat dalam
transaksi jual beli tanah dan bangunan. Penelitian ini
merupakan suatu penelitian hukum normatif yang
menggunakan pendekatan peraturan perundang-
undangan dan pendekatan kasus. Hasil penelitian
menunjukkan bahwa Notaris memiliki kewenangan di


bidang pertanahan sesuai dengan Pasal 15 ayat (2) huruf $\mathrm{f}$ Undang-Undang Nomor 2 Tahun 2014 tentang Jabatan Notaris, tetapi tidak memiliki wewenang untuk menahan/menyimpan sertipikat. Akibat hukum berkaitan dengan kewenangan notaris menahan atau menyimpan sertifikat notaris dapat dikenakan sanksi antara lain berupa sanski teguran lisan maupun tertulis dari Majelis Pengawas Wilayah.

\section{Pendahuluan}

Notaris merupakan pemegang jabatan terhormat pemberian Negara berdasarkan Undang-Undang, yang memiliki pengertian yaitu seseorang yang diberikan kewenangan dalam menghadirkan produk hukum berupa akta. Keberadaan Notaris bertujuan dapat memberikan pelayanan dalam memberikan bantuan kepada masyarakat dalam memenuhi kebutuhan pembuktian tertulis memiliki sifat autentik yaitu berupa bentuk akta. Selanjutnya dalam Pasal 1868 Kitab Undang-Undang Hukum Perdata (selanjutnya disebut KUHPer) juga ditentukan yaitu akta otentik yang dibuat sesuai ketentuan perundang-undangan melalui kuasa pejabat publik yang berkaitan dengan hal tersebut serta tempat pelaksanaan pembuatan akta. Notaris dalam menjalankan tugas jabatannya wajib bertindak berdasarkan ketentuan hukum untuk menciptakan kepastian pihak-pihak yang bersepakat, dan terkait perkara maka akta tersebut bisa menjadi pedoman bagi pembuatnya. ${ }^{1}$ Termasuk dalam hal jual beli yang sudah dilakukan masyarakat sejak zaman dahulu. Jual beli merupakan persetujuan untuk memberikan/memindahkan hak atas kepemilikan berupa barang yang diukur menurut harga untuk menerima pembayaran sesuai kesepakatan. ${ }^{1}$ Sedangkan menurut Pasal 1457 KUHPer. dinyatakan jual beli merupakan kesepakatan antara pihak yang satu agar mendapatkan benda serta pihak lain agar menerima pembayaran sesuai yang disetujui.

Dalam kelancaran administrasi mengenai kegiatan jual beli, Notaris membuat suatu akta pengikatan jual beli agar pihak-pihak saling terikat (sebelum dibuatkan Akta Jual Beli oleh Pejabat Pembuat Akta Tanah, selanjutnya disebut PPAT) sebagai syarat adanya transaksi jual beli tanah dan/atau bangunan. ${ }^{2}$ Pengikatan tersebut lahir disebabkan belum dipenuhinya unsur-unsur untuk menjual atau untuk membeli tanah sehingga proses diselesaikannya transaksi menjadi tersendat. Tidak ditemukan suatu pembeda antara perjanjian secara umum dengan perjanjian jual beli yang hadir berdasarkan keterbukaan Buku III KUHPer dengan pemberian sebebas-bebasnya serta sebesar-besarnya terhadap subjek hukum dalam melaksanakan persetujuan tanpa mempemasalahkan isi dan bentuknya dengan tetap mengindahkan aturan hukum, agama, dan tata susila. Pada umumnya, suatu perjanjian mengenai tanah terkandung

\footnotetext{
${ }^{1}$ Fitriyeni, C. E. (2012). Tanggung Jawab Notaris terhadap Penyimpanan Minuta Akta sebagai Bagian dari Protokol Notaris. KANUN: Jurnal Ilmu Hukum, 14(3), 391-404. h. 392.

${ }^{1}$ Marwan, M. \& Jimmy. (2009). Kamus Hukum. Cet. I. Surabaya: Reality Publisher. h. 313.

${ }^{2}$ Silviana, A., Suharto, R., \& Laksita, S. D. (2017). Legalitas Kuasa dalam Akta Pengikatan Jual Beli Tanah sebagai Dasar Pembuatan Akta Jual Beli (Studi di Kota Semarang). Diponegoro Law Review, 6(1), 1-11. h. 7. Menurut Pasal 16 ayat (1) UUPA, jenis-jenis hak tanah yaitu: (a) hak milik; (b) hak guna usaha; (c) hak guna bangunan; (d) hak pakai; (e) hak sewa; (f) hak membuka tanah; (g) hak memungut hasil usaha; dan (h) hak-hak lainnya selain yang disebutkan yang akan ditetapkan dengan undang-undang.
} 
unsur-unsur wajib sebelum bisa dilaksanakannya perjanjian pokok sehingga tercapai tujuan akhir bagi pihak-pihak. ${ }^{3}$ Pada Pasal 1 angka 1 Peraturan Pemerintah Nomor 24 Tahun 2016 mengenai Perubahan Peraturan Pemerintah Nomor 37 Tahun 1998 mengenai Peraturan Jabatan PPAT (selanjutnya disebut PP Nomor 24 Tahun 2016), menetapkan PPAT sebagai pejabat umum dengan wewenang pengadaan akta-akta otentik tentang suatu perbuatan hukum tentang kepemilikan hak atas tanah atau rumah susun.

Dalam kasus yang berkembang di masyarakat, seperti contoh kasus pada tahun 2017 lalu, Notaris dan PPAT Elfita Achtar dengan wilayah tugas jabatannya di Kota Bukittinggi Provinsi Sumatera Barat yang tidak bisa menyerahkan empat Sertipikat Hak Guna Bangunan milik PT. Rahman Tamin yang merupakan syarat dibuatnya Akta Pengikatan Jual Beli atas kesepakatan kedua pihak, dikarenakan pihak pembeli melakukan pembayaran secara bertahap tidak dapat dibuatkan Akta Jual Beli. Pihak pertama yakni PT. Rahman Tamin (dalam likuidasi) melalui komisarisnya bernama Mustafa Gani berkehendak agar Sertipikat HGB dikembalikan. Sementara pihak yang membeli yaitu PT. Starvi Properti Indonesia dengan diwakili oleh Direktur Utama Edi Yosfi sudah membayar uang muka sebesar sepuluh milyar rupiah. ${ }^{4}$ Berdasarkan hal tersebut, Mustafa Gani yang merupakan Direktur Utama PT. Rahman Tamin melaporkan Notaris/PPAT Elfita Achtar dengan tuduhan penggelapan. Likuidasi memiliki arti pembubaran atau penghapusan. ${ }^{5}$ Berdasarkan hal tersebut, maka likuidasi dilakukan dalam rangka pembubaran Badan Hukum Perseroan Terbatas (PT).

Dalam ketentuan 16 ayat (1) huruf b Undang-Undang Nomor 2 Tahun 2014 tentang Jabatan Notaris (selanjutnya disebut UUJN), ditentukan yaitu Notaris harus mengadakan akta dan menuangkannya menjadi Minuta Akta serta melakukan penyimpanan di protokol profesinya. Definisi minuta akta adalah terdapat pada ketentuan 1 angka 8 UUJN, yaitu akta yang asli atau sesungguhnya dengan ditandatangani oleh penghadap, saksi, serta Notaris, kemudian disimpan sebagai bagiannya Protokol Notaris. Kemudian pengertian protokol Notaris terdapat dalam Pasal 1 angka 13 UUJN, yaitu persatuan naskah-naskah menjadi arsip negara yang wajib dilakukan penyimpanan dan pemeliharaan oleh Notaris. Sama halnya Notaris, PPAT juga menyimpan akta nya dalam suatu protokol PPAT yang ditegaskan dalam Pasal 1 angka 5 PP Nomor 24 Tahun 2016, menetapkan yaitu persatuan naskah-naskah PPAT berisi daftar akta, akta asli, warkah pendukung akta, arsip laporan, agenda, dan surat-surat lainnya yang wajib dijaga serta dirawat dengan baik.

Berdasarkan pemaparan tersebut diatas, dapat dikemukakan persoalan-persoalan yang diangkat dalam tulisan ini, apakah yang menjadi kewenangan Notaris dalam transaksi jual beli tanah dan bangunan menurut UUJN? Serta bagaimana akibat hukum bagi Notaris apabila terjadi pelanggaran dalam transaksi jual beli tanah dan bangunan dalam hal penahanan sertipikat? Tulisan ini bertujuan untuk memahami dan menganalisa tentang akibat hukum bagi Notaris apabila terjadi pelanggaran dalam transaksi jual beli tanah dan bangunan berkaitan dengan penahanan sertipikat.

Pengaturan tentang kewenangan Notaris untuk membuat produk hukum berupa akta merupakan cerminan dari tugas jabatan Notaris sebagaimana diatur dalam UUJN.

\footnotetext{
${ }^{3}$ Baswedan, T. B. T. (2014). Kajian Yuridis Pembatalan Akta Pengikatan Jual Beli (Pjb) Tanah yang Dibuat Dihadapan Notaris. Premise Law Jurnal, 4. h. 4-5.

4 Abdi, F. (2017). https://sumbar.antaranews.com/berita/207862/pn-bukittinggi-vonis-bebas-Notariselfita-achtar-dalam-kasus-dugaan-penggelapan. diakses pada tanggal 12 Juni pukul 12:11.

${ }_{5}^{5}$ Marwan, M. \& Jimmy. op.cit. h. 411.
} 
Penahanan sertifikat dalam transaksi jual beli tanah dan bangunan kerap terjadi di kalangan Notaris. Studi kepustakaan yang dilakukan dalam penelitian ini adalah berdasarkan kasus dari Notaris Elfita Achtar dengan wilayah tugas jabatannya di Kota Bukittinggi Provinsi Sumatera Barat melakukan penahanan sertipikat Hak Guna Bangunan selaku pemilik dari PT. Rahman Tamin. ${ }^{6}$ Selanjutnya, hasil studi dari Meta Suriyani pada tahun 2015 mengkaji legalitas kewenangan Notaris/PPAT dalam menahan Sertipikat Hak Milik karena adanya pembatalan jual beli yang dilakukan dengan wilayah tugasnya di Kota Jayapura Provinsi Papua. ${ }^{7}$ Berkaitan dengan akibat hukum terhadap Notaris/PPAT apabila terjadi pelanggaran dalam transaksi jual beli tanah dan bangunan dapat dicermati hasil studi dari Akmelen Zulda Putra pada tahun 2010. Adapun tulisan ini lebih memfokuskan kajian pada akibat hukum dibuatnya akta jual beli yang bertentangan dalam tata cara dibuatnya akta PPAT. 8

\section{Metode Penelitian}

Menurut Peter Mahmud Marzuki, penelitian hukum merupakan langkah agar mendapatkan pengaturan hukum, landasan-landasan hukum atau mengenai pendapat-pendapat hukum agar mendapatkan jawaban terhadap permasalahanpermasalahan yang dikaji. ${ }^{9}$ Berdasarkan definisi tersebut maka dalam penelitian ini, digunakan metode penelitian hukum normatif dengan meninjau tentang ketentuan perundang-undangan mengenai permasalahan yang akan diteliti, antara lain adanya kekosongan norma dalam peraturan UUJN terkait perlindungan hukum bagi Notaris saat menahan sertipikat dalam transaksi jual beli.

Pendekatan perundang-undangan (statue approach) serta pendekatan kasus (the case approach) digunakan dalam studi ini untuk mengkaji kewenangan notaris menahan sertifikat. Sumber bahan hukum primer, sumber bahan hukum sekunder, serta bahan hukum tersier merupakan bahan-bahan hukum yang dipergunakan dalam penelitian ini. Sumber primer antara lain perundang-undangan, berupa UUJN juncto UU Perubahan Atas UUJN, dan Kitab Undang-Undang Hukum Perdata. Kemudian sumber sekunder didapat dengan mengkaji kepustakaan yaitu buku-buku hukum, pendapat-pendapat hukum, maupun internet. Sedangkan sumber tersier berasal dari Kamus Hukum dan Kamus Besar Bahasa Indonesia.

Pengumpulan bahan hukum dilaksanakan melalui studi pustaka dengan menggunakan sistem bola salju (snow ball). ${ }^{10}$ Yakni bahan-bahan hukum dikumpulkan berdasarkan topik bahasan yang ada hubungannya dengan permasalahan dalam penelitian. Informasi-informasi kepustakaan mengenai hukum yang didapat selanjutnya ditelaah menggunakan teknik deskriptif, selanjutnya diberikan penilaian (evaluasi), kemudian dilakukan interpretasi atau penafsiran hukum untuk selanjutnya disimpulkan dengan menggunakan argumentasi. ${ }^{11}$

\section{Hasil Dan Pembahasan}

\footnotetext{
${ }^{6}$ Abdi, Fathul. loc.cit.

${ }^{7}$ Suriyani, M. (2015). Legalitas Kewenangan Notaris/PPAT Dalam Menahan Sertifikat Hak Milik Karena Adanya Pembatalan Jual Beli. Jurnal Hukum Samudra Keadilan, 10(2), 274-291. h. 280.

${ }^{8}$ Putra, A. Z. (2010). Akibat Hukum Dari Pembuatan Akta Jual Beli Tanah Yang Tidak Sesuai Dengan Tata Cara Pembuatan Akta Ppat. Doctoral dissertation, Universitas Diponegoro. h. 12.

${ }^{9}$ Marzuki, P. (2011). Penelitian Hukum, Jakarta: Kencana Prenada Media Group. h. 35.

${ }^{10}$ Diantha, I. M. P. (2016). Metode Penelitian Hukum Normatif Dalam Justifikasi Teori Hukum, Cet. I, Jakarta: Prenada Media Group. h. 149.

${ }^{11}$ Ibid. h. 181.
} 


\subsection{Kewenangan Notaris Dalam Transaksi Jual Beli Tanah dan Bangunan berdasarkan Undang-Undang Nomor 2 Tahun 2014 tentang Jabatan Notaris}

Kewenangan (atau biasa dikenal dengan wewenang) adalah perbuatan hukum yang diemban oleh profesi tertentu berlandaskan ketentuan-ketentuan/kaidah-kaidah undang-undang yang sah mengatur profesi tersebut. ${ }^{12}$ Dalam definisi lain, diartikan menjadi kapasitas dalam melaksanakan semua perbuatan hukum yang menyebabkan timbulnya resiko hukum, serta termasuk muncul dan menghilangnya akibat hukum. Terdapat 3 (tiga) sumber kewenangan yang dikutip dari pendapat H.D. Van Wijk/Willem Konijnenbelt yaitu:13

a. Atribusi, yaitu diberikannya kekukasaan pemerintahan dari pembuat undangundang terhadap bagian-bagian pemerintahan;

b. Delegasi, yaitu proses melimpahkan kekuasaan pemerintahan dari atasan kepada bawahannya;

c. Mandat, yaitu pemerintahan berkeinginan agar kekuasaannya dilaksanakan oleh organ lain dengan tetap menggunakan namanya.

Wewenang Notaris saat melaksanakan tugas dan jabatannya sebagai pejabat publik adalah wewenang yang didapat secara atributif berdasarkan UUJN. Profesi tersebut memerlukan adanya konsekuensi secara pribadi ataupun sosial mengenai kepatutan pada nilai-nilai hukum positif serta bersedia patuh terhadap kode etik guna mempererat nilai hukum positif yang terdahulu. ${ }^{14}$ Sebagaimana diatur di dalam Pasal 15 UUJN, Notaris berwenang untuk membuat produk hukum berupa Akta autentik terhadap seluruh perbuatan, perjanjian, dan penetapan sesuai ketentuan-ketentuan hukum yang berlaku dan/atau yang diinginkan oleh para pihak, menetapkan ketentuan tanggal akta tersebut dibuat, melakukan penyimpanan terhadap dokumendokumen akta, memberikan grosse, salinan dan kutipan akta, yang dilaksanakan selama akta tersebut tidak menjadi kewenangan pejabat atau pihak lain yang ditentukan oleh ketentuan undang-undang.

Pasal 16 ayat (1) huruf b UUJN menentukan bahwa saat melaksanakan profesinya, Notaris berhak mengadakan akta berbentuk minuta Akta serta melakukan penyimpanan yang merupakan bagian dari protokol Notaris. Sehingga, Notaris/PPAT wajib menyimpan Minuta Akta yang sama bunyinya dan dalam bentuk aslinya sebagai bagian dari protokol Notaris. Berdasarkan ketentuan peraturan perundang-undangan tersebut di atas, Notaris/PPAT tidak berwenang menyimpan/menahan sertipikat, ditegaskan kembali pada Pasal 1725 KUHPer dengan ketetuan yaitu apabila yang memberi titipan meminta barang yang dititipkan, untuk itu wajib diberikan saat itu juga meskipun telah ada penetapan dalam perjanjian mengenai waktu mengembalikan, selain karena barang tersebut sudah disita dari yang memberi titipan. Notaris harus dapat menciptakan kepastian, ketertiban, dan perlindungan hukum dengan umumnya memerlukan pembuktian sebagai penentu secara terang mengenai

\footnotetext{
${ }^{12}$ Mido, M. T. C., Nurjaya, I. N., \& Safa'at, R. (2018). Tanggung Jawab Perdata Notaris terhadap Akta yang Dibacakan oleh Staf Notaris di Hadapan Penghadap. Lentera Hukum, 5(1), 156-173. h. 163. https://jurnal.unej.ac.id/index.php/eJLH/article/view/6288.

${ }^{13}$ Doly, D. (2016). Kewenangan Notaris dalam Pembuatan Akta yang berhubungan dengan Tanah. Negara Hukum, 2(2), 269-286. h. 275. http://jurnal.dpr.go.id/index.php/ hukum/article/view/217.

${ }^{14}$ Mowoka, V. P. (2014). Pelaksanaan Tanggung Jawab Notaris Terhadap Akta Yang Dibuatnya. Lex Et Societatis, 2(4). h. 59. https://ejournal.unsrat.ac.id/ index.php/lexetsocietatis/article/view/4671.
} 
hak dan kewajiban seseorang sebagai subjek hukum di kehidupan sosial menjadi suatu prinsip dari negara hukum. ${ }^{15}$

Notaris tidak berwenang untuk menyimpan/menahan sertipikat apapun termasuk Sertipikat Hak Guna Bangunan. Notaris hanya berwenang menyimpan Minuta Akta dalam protokol Notaris yang sama bunyinya dan dalam bentuk aslinya sesuai ketentuan dalam UUJN. Kemudian berdasarkan Pasal 32 ayat (1) PP 24/1997 diatur mengenai pengertian sertipikat, yaitu dokumen pembuktian hak yang sah dan tetap tentang keterangan fisik dan keterangan yuridis sesuai kandungan di dalamnya, selama tidak bertentangan dengan keterangan yang terdapat di surat ukur serta buku tanah hak yang bersangkutan.

Putusan Mahkamah Konstitusi: 009-014/PUU-III/2015 menentukan bahwa informasi dalam pembuatan akta oleh Notaris terkait pertanahan, bukan berupa perbuatanperbuatan hukum mengenai wewenang pelaksanaan aktanya adalah wewenang khusus serta mencirikan para Pejabat Pembuat Akta Tanah. Dalam transaksi jual beli, notaris berwenang untuk melaksanakan akta pengikatan jual beli apabila para pihak belum dapat membuat akta tersebut sebagai akibat adanya beberapa persyaratan yang belum terpenuhi. Seperti misalnya, pembayaran yang belum lunas atau dibayarkan secara bertahap, atau proses pemecahan sertipikat, belum dapat membayar pajak, atau kondisi tertentu lainnya yang tidak melanggar hukum. Notaris juga berwenang membuat akta pengikatan jual beli, sesuai Pasal 15 ayat (2) huruf f UUJN, sebelum pada akhirnya dapat dipenuhi seluruh syarat-syarat diadakannya akta jual beli oleh para pihak di hadapan pejabat yang berwenang sebagaimana ditentukan berdasarkan Pasal 2 ayat (2) huruf a PP 37/1998.

\subsection{Akibat Hukum Bagi Notaris Berkaitan dengan Penahanan Sertipikat Transaksi Jual Beli}

Dalam melaksanakan tugas jabatannya, seorang Notaris wajib menaati Kode Etik Notaris sebagai suatu kaidah moral yang penting dan diperlukan dengan adanya aturan yang mengatur. Merujuk Pasal 1 ayat (2) Kode Etik Notaris, kode etik merupakan "suatu norma luhur berdasarkan ketentuan Perkumpulan Ikatan Notaris di Indonesia melalui keputusan Kongres Perkumpulan dan/atau berdasarkan ketentuan oleh serta terdapat pada aturan-aturan hukum berisikan mengenai ketentuan tersebut serta sah mengikat seluruh anggota Perkumpulan serta seluruh orang yang melaksanakan wewenang jabatan sebagai Notaris, meliputi didalamnya Para Pejabat Sementara Notaris, Notaris Pengganti pada saat menjalankan jabatan." Merujuk pada ketentuan tersebut, maka Notaris hendaknya bertingkah laku seesuai dengan norma-norma hukum atau norma kesusilaan, kemudian norma yang terdapat dalam aturan-aturan etika profesi tercantum pada Kode Etik Notaris. Notaris sebagai pejabat umum, memiliki kewenangan yang penting untuk membantu mewujudkan kepastian, ketertiban, dan perlindungan hukum untuk rakyat terkait pembuatan akta autentik. Dalam memberikan pelayanan bagi masyarakat, Notaris diharapkan dapat bersikap netral untuk menghindari terjadinya masalah-masalah di kemudian hari dikarenakan adanya berlawanan kebutuhan antar para pihak.

Dengan adanya Kode Etik Notaris, maka terdapat aspek pengawasan bagi Notaris agar tidak dapat berbuat sewenang-wenang. Karena Notaris memiliki peran untuk

\footnotetext{
${ }^{15}$ Nyoman, I. W. B. S. L., Martana, A., Tjukup, I. K. M. I. K., Dananjaya, N. S., \& Putra, I. P. R. A. (2016). Akta Notaris (Akta Otentik) Sebagai Alat Bukti Dalam Peristiwa Hukum Perdata. Acta Comitas, 180-188. h. 181.
} 
membuat akta autentik sehingga Notaris diharapkan dapat mengendalikan tingkah laku, kehormatan, serta martabatnya untuk menghindari pelanggaran hukum dikemudian hari. Dalam Pasal 67 ayat (1) UUJN mengatur mengenai pengawasan bagi Notaris, yaitu dilaksanakan oleh Menteri, yang merupakan Majelis Kehormatan Notaris yaitu organ yang memiliki wewenang serta memiliki tugas dalam membinaa serta mengawsi Notaris, sesuai dengan Pasal 1 ayat (6) UUJN. Mengenai terjadinya kesalahan yang disebabkan dari Notaris, terdapat beberapa sanksi untuk bisa diterapkan, yaitu: sanksi Kode Etik, sanksi dari Majelis Kehormatan Notaris di semua tingkatan, sanksi perdata, sanksi pidana, atau sanksi administratif. Sanksi merupakan gertakan hukum atau suatu media untuk memaksa agar menaati kaidah, undangundang, norma-norma hukum. ${ }^{16}$ Sanksi tersebut tidak dapat diterapkan secara bersamaan karena sanksi tersebut diberikan bagi lembaga yang memiliki kewenangan dalam memberikan sanksi, ${ }^{17}$ dengan tujuan agar Notaris memiliki tanggung jawab terhadap jabatan yang diemban dalam melaksanakan kewenangannya. Apabila terjadi suatu penyimpangan terhadap ketentuan Kode Etik Notaris, maka harus dipertanggungjawabkan berdasarkan tuntutan Kode Etik Notaris. ${ }^{18}$ Sesuai dengan ketentuan Pasal 14 Kode Etik Notaris, menentukan bahwa sanksi yang diberikan berupa pemberhentian sementara atau pemberhentian dengan hormat atau pemberhentian dengan tidak hormat melalui keanggotan Perkumpulan atas kesalahan sesuai yang tercantum pada Pasal 6 diatas harus dilakukan pemberitahuan dari Pengurus Pusat untuk Majelis Pengawas Daerah serta tembusannya disampaikan ke Menteri Hukum dan Hak Asasi Manusia Republik Indonesia. Sehingga apabila terjadi kekhilafan yang berkaitan dengan Kode Etik, maka akan diberikan sanksi sesuai ketentuan peraturan perundang-undnagan yang berlaku. Sedangkan wewenang Pengawasan Notaris oleh Majelis Pengawas Daerah, Majelis Pengawas Wilayah, dan Majelis Pengawas Pusat diberikan untuk bertanggung jawab dalam mengangkat dan memberhentikan Notaris sesuai ketentuan Pasal 67 ayat (2) UUJN.

Terdapat dua sanksi perdata yang diatur dalam Pasal 84 UUJN, yaitu agar akta dapat memiliki kekuatan pembuktian menjadi akta dibawah tangan atau akta batal demi hukum. Dengan adanya kecerobohan dalam bidang perdata yang dilakukan Notaris, maka ini dapat dijadikan argument oleh para pihak yang mendapat kerugian agar bisa melakukan tuntutan berupa penggantian biaya, ganti rugi, dan Bunga untuk Notaris. Terhadap kecerobohan dalam bidang pidana terhadap Notaris akan mendapatkan sanksi pidana sesuai ketentuan Kitab Undang-Undang Hukum Pidana, karena sanksi pidana tidak diatur dalam UUJN. Dalam perkara pidana, UUJN hanya mengatur tentang ketentuan persetujuan Majelis Kehormatan Notaris dalam kepentingan proses peradilan yang dituangkan pada Pasal 66 ayat (1) UUJN,19 yaitu: demi kebutuhan proses peradilan, penyidik, penuntut umum, atau hakim dengan persetujuan Majelis Kehormatan Notaris berwenang: (a) mengambil fotokopi Minuta Akta dan/atau suratsurat yang diletkatkan pada Minuta Akta atau Protokol Notaris dalam penyimpanan

\footnotetext{
${ }^{16}$ Marwan, M. \& Jimmy. op.cit. h. 552.

${ }^{17}$ Halim, R. M. (2015). Akibat Hukum Bagi Notaris Dalam Pelanggaran Penggandaan Akta. Lex Et Societatis, 3(4). h. 99. https://ejournal.unsrat.ac.id/index.php/lexetsocietatis/ article/view/8059.

${ }^{18}$ Tanugraha, J. (2018). Akibat Hukum Bagi Notaris Yang Rangkap Jabatan Sebagai Pejabat Negara. Hukum Bisnis dan Administrasi Negara, 1(2). h. 21. http://ejournal.unitomo.ac.id/ index.php/mh/article/view/735.

${ }^{19}$ Yo, R. J. (2013). Perlindungan Hukum Terhadap Notaris Dalam Proses Peradilan Pidana Berkaitan Dengan Akta yang Dibuatnya Menurut Undang-undang Nomor 30 Tahun 2004 Tentang Jabatan Notaris. Calyptra, 2(2), 1-16. h. 3. http://journal.ubaya.ac.id/ index.php/jimus/article/view/731/0.
} 
Notaris, dan (b) memanggil Notaris untuk hadir dalam pemeriksaan yang berkaitan dengan Akta atau Protokol Notaris sesuai yang terdapat dalam penyimpanan Notaris". Dalam hal pemidanaan, diperlukan suatu batasan, seperti jika terdapat perlakuan hukum oleh Notaris yang membuat akta secara sadar penuh serta menyepakati agar dapat menjadi dasar dalam melaksanakan tindak pidana melibatkan Notaris yang apabila diukur, terdapat pelanggaran atau ketidaksesuaian berdasarkan UUJN.20 Sedangkan sanksi administratif yaitu berupa peringatan atau teguran awal bagi Notaris agar tidak berbuat kecerobohan lagi. Hukuman berupa peringatan tertulis kepada Notaris hanya bisa disampaikan oleh Majelis Pengawas Wilayah. ${ }^{21}$

Berdasarkan uraian diatas, sanksi dapat dijatuhkan kepada Notaris hanya jika terdapat pelanggaran saat pelaksanaan jabatannya yaitu mengenai hal menyimpan atau menahan sertipikat dalam proses pembuatan akta. Apabila terbukti adanya pelanggaran tersebut maka Notaris akan mendapatkan sanksi berupa teguran lisan serta tertulis oleh Majelis Pengawas Wilayah yang memberikan usulan mengenai sanksi bagi Notaris dari Majelis Pengawas Pusat yaitu: (1) pemberhentian sementara 3 (tiga) bulan sampai dengan 6 (enam) bulan; atau (2) pemberhentian dengan tidak hormat, sesuai dengan Pasal 73 UUJN. Penahanan sertipikat merupakan suatu pelanggaran terhadap isi Pasal 1725 KUHPer. Pelanggaran oleh seorang Notaris akan menyebabkan produk hukum berupa akta semata-mata menjadi akta dibawah tangan atau akta menjadi batal demi hukum.

\section{Kesimpulan}

Notaris memiliki kewenangan dalam bidang pertanahan sesuai Pasal 15 ayat (2) huruf b Undang-Undang Nomor 2 Tahun 2014 tentang Jabatan Notaris UUJN, selama tidak membuat akta-akta otentik mengenai hak atas tanah atau Hak Milik Atas Satuan Rumah Susun yang merupakan kewenangan PPAT. Notaris memiliki kewenangan untuk membuat akta dibidang pertanahan sepanjang kewenangan tersebut tidak dimiliki PPAT, seperti membuat akta pengikatan jual beli dan akta kuasa menjual yang menjadi dasar bagi PPAT dalam proses pembuatan akta jual beli. Mengenai tindakan menahan sertipikat yang dilakukan oleh Notaris tidak diatur dalam UUJN, sehingga Notaris tidak memiliki kewenangan untuk menahan sertipikat apapun dalam proses pembuatan akta. Berdasarkan Pasal 1725 KUHPer, akibat hukum bagi Notaris yang melakukan pelanggaran dalam transaksi jual beli dengan menahan sertipikat pada saat proses pembuatan akta Notaris, dikenakan sanksi antara lain pengenaan hukuman berupa teguran lisan maupun tertulis dari Majelis Pengawas Wilayah.

Pemerintah hendaknya dapat memberikan kejelasan mengenai kewenangan bagi Notaris terkait pembuatan akta di bidang pertanahan agar dapat menciptakan suatu kepastian hukum. Sementara tindakan menahan seritipikat yang dilakukan oleh Notaris/PPAT agar ke depannya dapat dihindari dalam proses transaksi jual beli. Kemudian bagi Notaris, hendaknya dapat memiliki kesadaran dan sikap menjaga harkat dan martabat Jabatan Notaris agar tidak ada lagi ke depannya tindakan menahan sertipikat dalam proses transaksi jual beli serta benar-benar memahami dan mengimplementasikan peraturan perundang-undangan mengenai jabatan Notaris agar dapat terhindar dari permasalahan-permasalahan di kemudian hari. Kewenangan

\footnotetext{
${ }^{20}$ Setiabudhi, I. K. R., \& Swardhana, G. M. (2017). Sanksi Hukum Terhadap Notaris Yang Melanggar Kewajiban dan Larangan Undang-Undang Jabatan Notaris. Acta Comitas, 110-121. h. 112.

${ }^{21}$ Azyati, N. A. (2015). Pemberian Sanksi Terhadap Notaris Yang Telah Dijatuhi Pidana Dengan Ancaman Hukuman Kurang Dari Lima Tahun. Kumpulan Jurnal Mahasiswa Fakultas Hukum. h. 10. http://hukum.studentjournal.ub.ac.id/index.php/hukum/article/view/1405.
} 
yang diberikan kepada Notaris adalah amanah sehingga menjadi sangat penting apabila Notaris harus selalu berhati-hati dalam melaksanakan tanggung jawabnya sebagai pejabat publik.

\section{Ucapan terima Kasih (Acknowledgments)}

Artikel ini disarikan dan dikembangkan lebih lanjut dari Tesis yang disusun oleh penulis pada Program Studi Magister Kenotariatan Fakutas Hukum Universitas Udayana. Untuk itu, penulis mengucapkan terima kasih kepada para Pembimbing, Pimpinan, dan Staf pada program studi tersebut.

\section{Daftar Pustaka}

\section{Buku}

Diantha, I. M. P. (2016). Metode Penelitian Hukum Normatif Dalam Justifikasi Teori Hukum, Cet. I, Jakarta: Prenada Media Group.

Marwan, M. \& Jimmy. (2009). Kamus Hukum. Cet. I. Surabaya: Reality Publisher.

Marzuki, P. M. (2011). Penelitian Hukum, Jakarta: Kencana Prenada Media Group.

\section{Jurnal}

Azyati, N. A. (2015). Pemberian Sanksi Terhadap Notaris Yang Telah Dijatuhi Pidana Dengan Ancaman Hukuman Kurang Dari Lima Tahun. Kumpulan Jurnal Mahasiswa Fakultas Hukum. http://hukum.studentjournal. ub.ac.id/index.php/hukum/article/view/1405.

Baswedan, T. B. T. (2014). Kajian Yuridis Pembatalan Akta Pengikatan Jual Beli (Pjb) Tanah yang Dibuat Dihadapan Notaris. Premise Law Jurnal, 4. https://www.neliti.com/publications/14006/kajian-yuridis-pembatalan-aktapengikatan-jual-beli-pjb-tanah-yang-dibuat-dihada.

Doly, D. (2016). Kewenangan Notaris dalam Pembuatan Akta yang berhubungan dengan Tanah. Negara Hukum, 2(2), 269-286. http://jurnal.dpr.go.id Lindex.php/ hukum/article/view/217.

Fitriyeni, C. E. (2012). Tanggung Jawab Notaris terhadap Penyimpanan Minuta Akta sebagai Bagian dari Protokol Notaris. KANUN: Jurnal Ilmu Hukum, 14(3), 391404. http://www.jurnal.unsyiah.ac.id/kanun/article/view/6221/5117.

Halim, R. M. (2015). Akibat Hukum Bagi Notaris Dalam Pelanggaran Penggandaan Akta. Lex Et Societatis, 3(4). https://ejournal.unsrat.ac.id/ index.php/lexetsocietatis/ article/view/8059.

Mido, M. T. C., Nurjaya, I. N., \& Safa'at, R. (2018). Tanggung Jawab Perdata Notaris terhadap Akta yang Dibacakan oleh Staf Notaris di Hadapan Penghadap. Lentera Hukum, 5(1), 156-173. https://jurnal.unej.ac.id/ index.php/eJLH/article/view/6288. 
Mowoka, V. P. (2014). Pelaksanaan Tanggung Jawab Notaris Terhadap Akta Yang Dibuatnya. Lex Et Societatis, 2(4). https://ejournal.unsrat.ac.id/ index.php/lexetsocietatis/article/view/4671.

Nyoman, I. W. B. S. L., Martana, A., Tjukup, I. K. M. I. K., Dananjaya, N. S., \& Putra, I. P. R. A. (2016). Akta Notaris (Akta Otentik) Sebagai Alat Bukti Dalam Peristiwa Hukum Perdata. Acta Comitas, 180-188.

Setiabudhi, I. K. R., \& Swardhana, G. M. (2017). Sanksi Hukum Terhadap Notaris Yang Melanggar Kewajiban dan Larangan Undang-Undang Jabatan Notaris. Acta Comitas, 110-121.

Silviana, A., Suharto, R., \& Laksita, S. D. (2017). Legalitas Kuasa dalam Akta Pengikatan Jual Beli Tanah sebagai Dasar Pembuatan Akta Jual Beli (Studi di Kota Semarang). Diponegoro Law Review, 6(1), 1-11. https://media.neliti.com/media/publications/69912-ID-legalitas-kuasa-dalamakta-pengikatan-ju.pdf.

Suriyani, M. (2015). Legalitas Kewenangan Notaris/PPAT Dalam Menahan Sertifikat Hak Milik Karena Adanya Pembatalan Jual Beli. Jurnal Hukum Samudra Keadilan, 10(2), 274-291. http://ejurnalunsam.id/ index.php/jhsk/article/view/126.

Tanugraha, J. (2018). Akibat Hukum Bagi Notaris Yang Rangkap Jabatan Sebagai Pejabat Negara. Hukum Bisnis dan Administrasi Negara, 1(2). http:// ejournal.unitomo.ac.id/ index.php/mh/article/view/735.

Yo, R. J. (2013). Perlindungan Hukum Terhadap Notaris Dalam Proses Peradilan Pidana Berkaitan Dengan Akta yang Dibuatnya Menurut Undang-undang Nomor 30 Tahun 2004 Tentang Jabatan Notaris. Calyptra, 2(2), 1-16. http://journal.ubaya.ac.id/ index.php/jimus/article/view/731/0.

\section{Disertasi}

Putra, A. Z. (2010). Akibat Hukum Dari Pembuatan Akta Jual Beli Tanah Yang Tidak Sesuai Dengan Tata Cara Pembuatan Akta Ppat. Doctoral dissertation, Universitas Diponegoro. http://ejurnalunsam.id/index.php/jhsk/article/view/126.

\section{Internet}

Abdi, F. (2017). https://sumbar.antaranews.com/berita/207862/pn-bukittinggi-vonisbebas-Notaris-elfita-achtar-dalam-kasus-dugaan-penggelapan. diakses pada tanggal 12 Juni pukul 12:11. 